\title{
CORROSION BEHAVIOR OF 304L STAINLESS STEEL IN A B-Li COOLANT FOR A NUCLEAR POWER PLANT
}

\author{
KOROZIJA NERJAVNEGA JEKLA 304L V BOR-LITIJEVEM \\ HLADILU ZA JEDRSKO ELEKTRARNO
}

\author{
Zhaohui Tian', Lijun Song ${ }^{1 *}$, Kewei Fang1, Genxian Lin', Huiling Zhou ${ }^{2 *}$ \\ ${ }^{1}$ Suzhou Nuclear Power Research Institute, 1788 Xihuan Road, Suzhou 215004, China \\ ${ }^{2}$ School of Materials Science and Engineering, Jiangsu University of Science and Technology, 2 Mengxi road, Zhenjiang 212003, China
}

Prejem rokopisa - received: 2018-12-12; sprejem za objavo - accepted for publication: 2019-03-27

doi: $10.17222 / \mathrm{mit} .2018 .269$

\begin{abstract}
The corrosion behavior of 304L stainless steel (SS) in B/Li solutions with different concentrations was studied by means of X-ray diffraction (XRD), scanning electron microscope (SEM), potentiodynamic polarization and electrochemical impedance spectroscopy (EIS) measurement. The results showed that the oxide film formed at high temperature and a high pressure water is mainly composed of magnetite and the oxide film formed in a $1000 \mathrm{mg} / \mathrm{L} \mathrm{B}$ and $2.2 \mathrm{mg} / \mathrm{L} \mathrm{Li}$ solution is thicker than that in a $2000 \mathrm{mg} / \mathrm{L} \mathrm{B}$ and $3.5 \mathrm{mg} / \mathrm{L} \mathrm{Li}$ solution. The outer surface oxide particles' size and inner film uniformity is affected by the B/Li concentration. The pitting potential and the modulus of impedance of the $304 \mathrm{~L}$ in $1000 \mathrm{mg} / \mathrm{L} \mathrm{B}$ and $2.2 \mathrm{mg} / \mathrm{L} \mathrm{Li}$ solutions were higher than the $2000 \mathrm{mg} / \mathrm{L} \mathrm{B}$ and $3.5 \mathrm{mg} / \mathrm{L} \mathrm{Li}$ solutions. The solution of $1000 \mathrm{mg} / \mathrm{L} \mathrm{B}$ and $2.2 \mathrm{mg} / \mathrm{L} \mathrm{Li}$ is beneficial for the corrosion resistance, because of forming a stable oxide film on the $304 \mathrm{~L}$ surface.

Keywords: 304L SS, corrosion, oxide film
\end{abstract}

Avtorji v članku opisujejo študijo korozijskega obnašanja nerjavnega jekla vrste 304L v različnih koncentracijah raztopine bora in litija (B/Li). V ta namen so za analize uporabljali rentgensko difrakcijo (XRD), vrstično elektronsko mikroskopijo (SEM), potenciodinamično polarizacijo (PDP) in elektrokemijsko impedančno spektroskopijo (EIS). Rezultati kažejo, da je pri visoki temperaturi in tlaku nastali oksidni film v glavnem sestavljen iz magnetita. Oksidni film, ki je nastal v raztopini $1000 \mathrm{mg} / \mathrm{L}$ bora in $2,2 \mathrm{mg} / \mathrm{L}$ litija, je debelejši kot tisti, ki je nastal v raztopini $2000 \mathrm{mg} / \mathrm{L}$ bora in $3,5 \mathrm{mg} / \mathrm{L}$ litija. Formiranost zunanje površine oksidnih delcev in notranjega filma, je posledica koncentracije $\mathrm{B} / \mathrm{Li}$ raztopine. Jamičasti potencial in impedančni modul nerjavnega jekla 304L v raztopini $1000 \mathrm{mg} / \mathrm{L} \mathrm{B}$ in $2,2 \mathrm{mg} / \mathrm{L} \mathrm{Li}$ je večji kot v raztopini $2000 \mathrm{mg} / \mathrm{L} \mathrm{B}$ in $3,5 \mathrm{mg} / \mathrm{L} \mathrm{Li}$. Raztopina $1000 \mathrm{mg} / \mathrm{L} \mathrm{B}$ in $2,2 \mathrm{mg} / \mathrm{L} \mathrm{Li}$ je glede odpornosti proti koroziji primernejša, ker tvori stabilnejši oksid na površini izbranega nerjavnega jekla 304L.

Ključne besede: nerjavno jeklo 304L, korozija, oksidni film

\section{INTRODUCTION}

The $304 \mathrm{~L}$ and $316 \mathrm{~L}$ stainless steels are commonly used as the primary loop line, reactor internals and control rod drive package, i.e., the key equipment of a PWR. In the primary loops of a PWR, stainless-steel material is exposed to a harsh hydrochemical environment that features high temperature and high pressure. So, a low corrosion rate should be ensured to reduce the activation of the corrosion products in the core. It is reported that the amount of corrosion products in the coolant, the deposition rate in the core and the radiation field outside the core should be effectively reduced when the $\mathrm{pH}$ of the coolant increased from 6.9 to $7.2-7.4 .{ }^{1}$ The operation experiences of the Sizewell B nuclear power plant showed that the corrosion product concentration decreased by two orders of magnitude when the $\mathrm{pH}$ of the coolant increased from 6.9 to 7.7 at $292{ }^{\circ} \mathrm{C} .{ }^{2,3}$ The oxide film has a great influence on the corrosion rate of stainless steel in $290 \pm 0.5^{\circ} \mathrm{C}$ and $10 \mathrm{MPa}$ water. ${ }^{4-7}$ The struc-

*Corresponding author's e-mail:

songlijun@cgnpc.com.cn (Lijun Song),hlzhou@just.edu.cn (Huiling Zhou) ture and properties of the oxide film of 304L SS in hightemperature water are not only affected by the properties of the material itself, but also affected by the water chemistry, such as $\mathrm{pH}$, dissolved oxygen and so on..$^{8,9}$ The relationship between the growth of the oxide film and the corrosion resistance of the stainless steel with the concentration of $\mathrm{B}, \mathrm{Li}$ and $\mathrm{pH}$ should be further investigated.

In this paper, the corrosion behavior of 304L stainless steel (SS) in $\mathrm{B} / \mathrm{Li}$ solutions with different concentrations was studied by means of X-ray diffraction XRD, scanning electron microscope (SEM), potentiodynamic polarization and electrochemical impedance spectroscopy (EIS) measurements to obtain the relation between the corrosion behavior of $304 \mathrm{~L}$ stainless steel and the concentration of the $\mathrm{B} / \mathrm{Li}$ ratio.

\section{EXPERIMENTAL PART}

The chemical compositions of 304L SS used in this study are shown in Table 1 . The 304L SS plate was cut into samples with dimensions of $(30 \times 20 \times 3) \mathrm{mm}$. One tested solution contained $2000 \mathrm{mg} / \mathrm{L} \mathrm{B}$ (from $\mathrm{H}_{3} \mathrm{BO}_{3}$ ) 
and $3.5 \mathrm{mg} / \mathrm{L} \mathrm{Li}$ (from $\mathrm{LiOH}$ ), and another solution contained $1000 \mathrm{mg} / \mathrm{L} \mathrm{B}$ (from $\mathrm{H}_{3} \mathrm{BO}_{3}$ ) and $2.2 \mathrm{mg} / \mathrm{L} \mathrm{Li}$ (from $\mathrm{LiOH}$ ). The sample was mechanically polished to 1200\# SiC emery paper, and then washed using ultrasound with acetone. The experiment was conducted in a static autoclave. The corrosion tests were controlled at $300{ }^{\circ} \mathrm{C}$, under a pressure of $10 \mathrm{MPa}$ for $720 \mathrm{~h}$. At the end of the test, the sample was washed with ionized water and dried using cold air.

Table 1: Chemical composition of 304L SS (w/\%)

\begin{tabular}{|c|c|c|c|c|c|c|c|}
\hline $\mathrm{C}$ & $\mathrm{Si}$ & $\mathrm{Mn}$ & $\mathrm{S}$ & $\mathrm{P}$ & $\mathrm{Ni}$ & $\mathrm{Cr}$ & $\mathrm{Fe}$ \\
\hline 0.015 & 0.32 & 1.89 & 0.002 & 0.018 & 9.27 & 18.33 & Balanced \\
\hline
\end{tabular}

A Cambridge-S360 scanning electron microscope (SEM) was applied to observe the oxide scale morphology. The surfaces of the samples were plated with a thin layer of $\mathrm{Ni}$ coating to avoid spoliation during sample preparation. The electrolyses nickel bath was composed of $30 \mathrm{~g} / \mathrm{L} \mathrm{NiSiO} \cdot 6 \mathrm{H}_{2} \mathrm{O}, 20 \mathrm{~g} / \mathrm{L} \mathrm{NaH} \mathrm{PO}_{2} \cdot \mathrm{H}_{2} \mathrm{O}, 10 \mathrm{~g} / \mathrm{L}$ $\mathrm{NaC}_{6} \mathrm{H}_{5} \mathrm{O}_{7} \cdot 2 \mathrm{H}_{2} \mathrm{O}$ and $20 \mathrm{~g} / \mathrm{L} \mathrm{NaC}_{2} \mathrm{H}_{3} \mathrm{O}_{2} \cdot 3 \mathrm{H}_{2} \mathrm{O}$. The $\mathrm{pH}$ value of the bath solution was adjusted to 4.5 using $\mathrm{H}_{2} \mathrm{SO}_{4}$ at $80{ }^{\circ} \mathrm{C}$. The oxide film sample was treated by a sensitize solution $(10 \mathrm{~g} / \mathrm{L} \mathrm{SnCl} 2$ and $1 \mathrm{ml} / \mathrm{L} 37 \% \mathrm{HCl})$ and an activation solution $\left(0.3 \mathrm{~g} / \mathrm{L} \mathrm{PdCl}_{2}\right) .{ }^{10}$ The samples were mounted with epoxy resin and polished down to $0.5 \mu \mathrm{m}$ before the metallurgical examination. The X-ray diffractions were recorded by a D/Max-2550pc diffrac- tometer equipped with a $\mathrm{Cu}$ anti-cathode $(40 \mathrm{kV} \pm 30 \mathrm{~mA})$. The lattice parameters were measured starting from $2 \theta$ at $20^{\circ}$ to $80^{\circ}$ in $0.05^{\circ}$ and $1 \mathrm{~s}$ steps.

The electrochemical tests were carried out using a VMP3 electrochemical workstation. The working electrodes were the $304 \mathrm{~L}$ with an exposed area of $1 \mathrm{~cm}^{2}$. Before the commencement of the measurements, the surface of the working electrode was polished down to the finest (1200) grit, rinsed with ethanol, placed in an ultrasonic acetone bath for about five min and air dried. All the working electrodes were ground by emery papers before use. A saturated calomel electrode (SCE) was used as the reference electrode and a platinum electrode was used as an auxiliary electrode. All the electrochemical measurements were carried out in the open air without stirring. One tested solution contained $2000 \mathrm{mg} / \mathrm{L} \mathrm{B}$ (from $\mathrm{H}_{3} \mathrm{BO}_{3}$ ) and $3.5 \mathrm{mg} / \mathrm{L} \mathrm{Li}(\mathrm{LiOH})$, and the other solution contained $1000 \mathrm{mg} / \mathrm{L} \mathrm{B}$ (from $\mathrm{H}_{3} \mathrm{BO}_{3}$ ) and $2.2 \mathrm{mg} / \mathrm{L} \mathrm{Li}(\mathrm{LiOH})$. The experiments were carried out at room temperature in naturally aerated solutions without stirring and the temperature of the tested solution was maintained at $25 \pm 1{ }^{\circ} \mathrm{C}$. The polarization curves were conducted at a sweep rate of $0.5 \mathrm{mV} / \mathrm{s}$. The impedance experiments were carried out using a $10 \mathrm{mV}$ root-mean-square perturbation from $10 \mathrm{kHz}$ to $10 \mathrm{mHz}$. The fitting was performed with Z-view software.

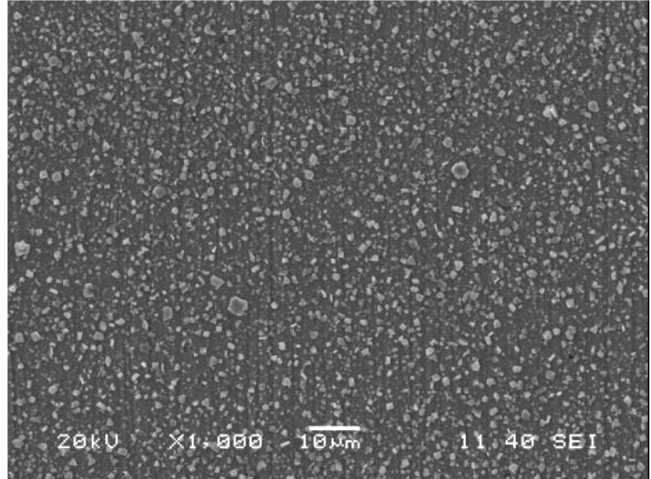

a ) $1000 \mathrm{mg} / \mathrm{L} \mathrm{B}+2.2 \mathrm{mg} / \mathrm{L} \mathrm{Li}$ solution

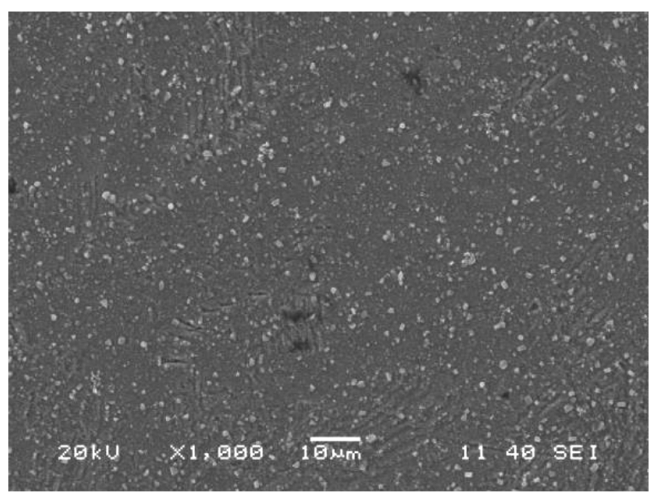

c) $2000 \mathrm{mg} / \mathrm{L} \mathrm{B}+3.5 \mathrm{mg} / \mathrm{L} \mathrm{Li}$ solution

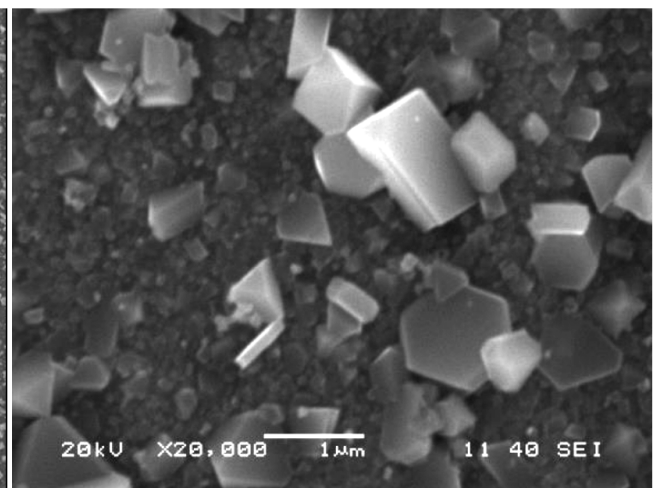

b ) $1000 \mathrm{mg} / \mathrm{L} \mathrm{B}+2.2 \mathrm{mg} / \mathrm{L} \mathrm{Li} \mathrm{solution}$

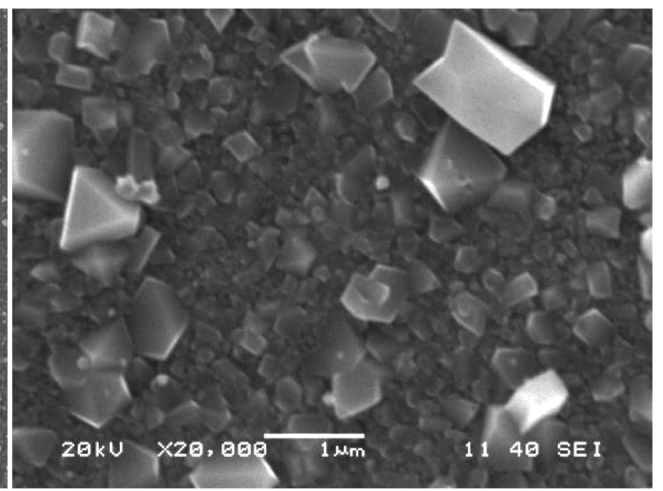

d) $2000 \mathrm{mg} / \mathrm{L} \mathrm{B}+3.5 \mathrm{mg} / \mathrm{L} \mathrm{Li}$ solution

Figure 1: Surface images of oxides on 304L SS immersed in B-Li solution 


\section{RESULTS AND DISCUSSION}

Figure 1 shows the surface morphology of the 304L SS after immersion in high-temperature and highpressure water for $720 \mathrm{~h}$. The surface morphology of the 304L SS is similar to each other after being immersion in the two tested solutions. The surface is covered with a layer of oxide film with regularly shaped oxide particles distributed evenly on the surface, as shown in Figure 1a and 1c. It can be seen that the number of large oxide particles formed on the 304L SS after being soaked in $1000 \mathrm{mg} / \mathrm{L} \mathrm{B}$ and $2.2 \mathrm{mg} / \mathrm{L} \mathrm{Li}$ solution is great than that in $2000 \mathrm{mg} / \mathrm{L} \mathrm{B}$ and $3.5 \mathrm{mg} / \mathrm{L} \mathrm{Li}$ solution. The particles' features can be identified, as shown in Figure 1b and 1d. It is clear that the size of the particles is different. The granular oxides are mainly nickel and iron oxides. ${ }^{11,12}$ According to the calculation by ChemWorks, ${ }^{13}$ the $\mathrm{pH}_{300}$ values of $1000 \mathrm{mg} / \mathrm{L} \mathrm{B}$ and $2.2 \mathrm{mg} / \mathrm{L} \mathrm{Li}$ solution is 7.01 at $300{ }^{\circ} \mathrm{C}$, and the $\mathrm{pH}_{300}$ values of $2000 \mathrm{mg} / \mathrm{L} \mathrm{B}$ and $3.5 \mathrm{mg} / \mathrm{L} \mathrm{Li}$ solutions is 6.92 . That is to say, the concentration of the $\mathrm{B} / \mathrm{Li}$ has a great influence on the growth and distribution of the particle oxides.

Figure 2 shows the XRD pattern of austenite and $\mathrm{Fe}_{3} \mathrm{O}_{4}$. It can be seen from Figure 2 that the oxides of 304L SS after immersion in both solutions are mainly composed of magnetite, and the metal substrate diffraction peak of the samples after immersion in $2000 \mathrm{mg} / \mathrm{L} \mathrm{B}$ and $3.5 \mathrm{mg} / \mathrm{L} \mathrm{Li}$ solution was higher than $1000 \mathrm{mg} / \mathrm{L} \mathrm{B}$ and $2.2 \mathrm{mg} / \mathrm{L}$ solution. The oxide film formed in $1000 \mathrm{mg} / \mathrm{L} \mathrm{B}+2.2 \mathrm{mg} / \mathrm{L} \mathrm{Li}$ solution is thicker than in the $2000 \mathrm{mg} / \mathrm{L} \mathrm{B}$ and $3.5 \mathrm{mg} / \mathrm{L} \mathrm{Li}$ solution, which is consistent with the results of the cross-section analysis in the later paper.

Figure 3 shows the cross-section of the oxide formed on 304L SS in two tested solutions for $720 \mathrm{~h}$. The oxide films contain a dual-layer structure, and there is no crack between the inner and the outer oxide layers. In the solution of $1000 \mathrm{mg} / \mathrm{L} \mathrm{B}$ and $2.2 \mathrm{mg} / \mathrm{L} \mathrm{Li}$, the inner oxide film of $304 \mathrm{~L} \mathrm{SS}$ is uniform and the thickness of which is about $400 \mathrm{~nm}$. The outer layer is composed of large crystalline oxides with a maximum size of $1.3 \mu \mathrm{m}$. In the solution of $2000 \mathrm{mg} / \mathrm{L} \mathrm{B}+3.5 \mathrm{mg} / \mathrm{L} \mathrm{Li}$, the thickness of inner layer is not uniform and there are no large particles in the outer layer. The denser the oxide forms on the surface, the lower the dissolution rate of the base metal. According to the results in Figure 1 and Figure 3, the oxide film formed in $2000 \mathrm{mg} / \mathrm{L} \mathrm{B}$ and $3.5 \mathrm{mg} / \mathrm{L} \mathrm{Li}$ solution is not uniform and the thickness of the oxide film is less than $100 \mathrm{~nm}$ in some areas. So, it is easy to form a uniform thicker oxide film in $1000 \mathrm{mg} / \mathrm{L} \mathrm{B}$ and $2.2 \mathrm{mg} / \mathrm{L} \mathrm{Li}$ solution when the solubility of the oxide film is lower in the higher $\mathrm{pH}$ solution. The EDS results showed that granular oxides are mainly nickel and iron oxides in Figure 3a. But EDS mapping in Figure 3b showed that granular oxides were not as good as in Figure 3a. A possible reason was that oxide particles were too small to be discernable by EDS.

Figure 4 shows the potentiodynamic polarization curve of $304 \mathrm{~L} \mathrm{SS}$ in two tested solutions. It can be seen from Figure 4 that the corrosion current density and corrosion potential of 304L stainless steel in two solutions is basically similar to each other. In both tested solutions, 304L SS has an obvious passivation zone in the anodic curves. The stable passive potential range of $304 \mathrm{~L} \mathrm{SS}$ in $1000 \mathrm{mg} / \mathrm{L} \mathrm{B}$ and $2.2 \mathrm{mg} / \mathrm{L} \mathrm{Li}$ solution is from -0.20 to $0.9 \mathrm{~V}_{\mathrm{SCE}}$, and second passivation peak at $0.69 \mathrm{~V}_{\text {SCE }}$. However, no apparent pitting potential can be observed. Secondary passivation occurred when the potential was higher than $0.69 \mathrm{~V}_{\mathrm{SCE}}$, which may be related to the instability of the passive film. ${ }^{11}$ The passivation range of $304 \mathrm{~L} \mathrm{SS}$ in $2000 \mathrm{mg} / \mathrm{L} \mathrm{B}$ and $3.5 \mathrm{mg} / \mathrm{L} \mathrm{Li}$ solution is $-0.2 \mathrm{~V}_{\mathrm{SCE}} \approx 0.67 \mathrm{~V}_{\mathrm{SCE}}$. According to the calculation by ChemWorks, ${ }^{13}$ the $\mathrm{pH}_{25}$ value of $1000 \mathrm{mg} / \mathrm{L} \mathrm{B}$ and $2.2 \mathrm{mg} / \mathrm{L} \mathrm{Li}$ solution is 6.55 and the $\mathrm{pH}_{25}$ value of $2000 \mathrm{mg} / \mathrm{L} \mathrm{B}$ and $3.5 \mathrm{mg} / \mathrm{L} \mathrm{Li}$ solution is 6.10 at $25^{\circ} \mathrm{C}$. So, the $\mathrm{pH}$ of the $\mathrm{B} / \mathrm{Li}$ solution affects the corrosion resistance of the $304 \mathrm{~L} \mathrm{SS}$ in $1000 \mathrm{mg} / \mathrm{L} \mathrm{B}$ and $2.2 \mathrm{mg} / \mathrm{L}$

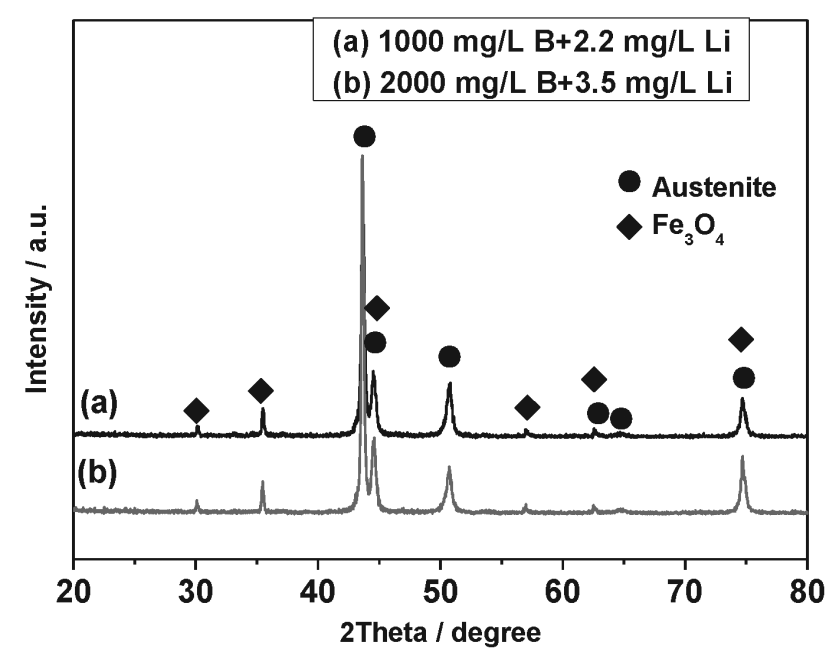

Figure 2: XRD images of oxides on 304L immersed in B-Li solution

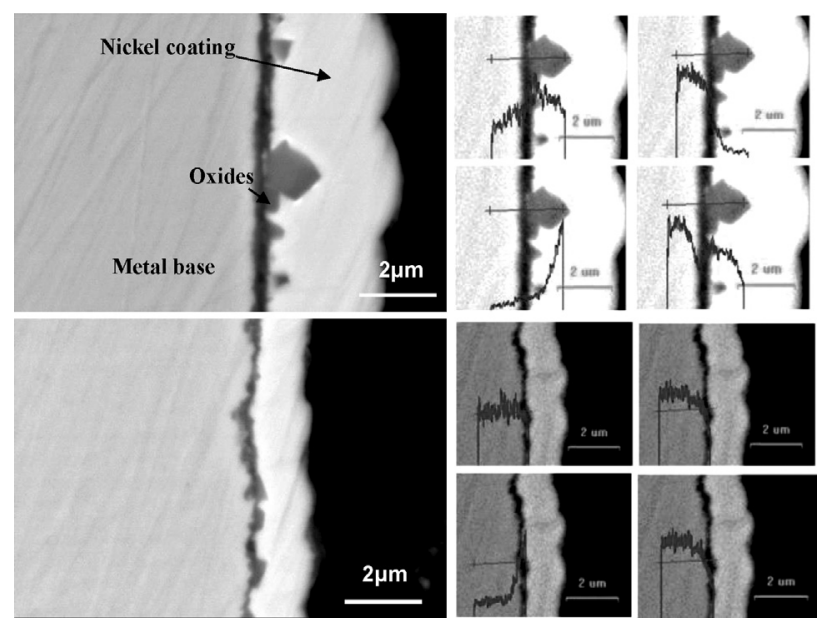

Figure 3: Cross-section profiles and EDS of oxides film on 304L SS immersed in B-Li solution 


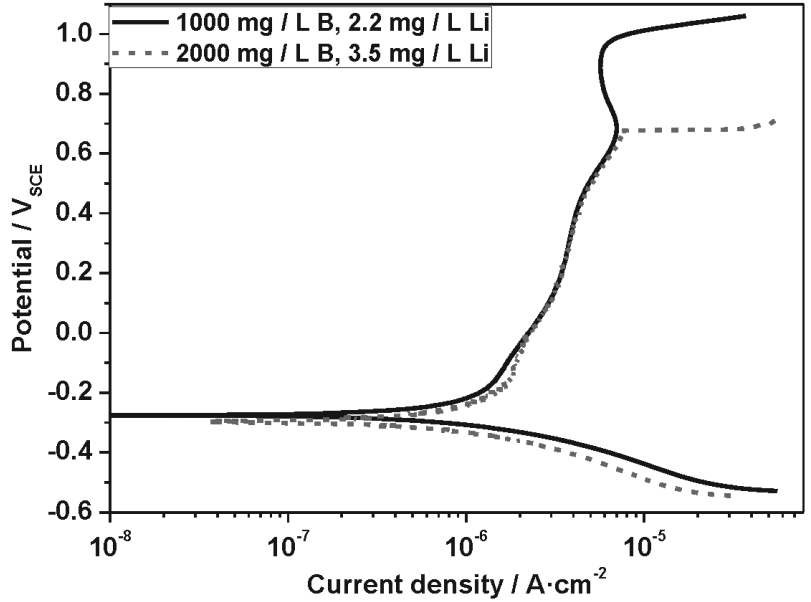

Figure 4: Potentiodynamic polarization curves of $304 \mathrm{~L}$ in B-Li solutions

Li solution better than the $2000 \mathrm{mg} / \mathrm{L} \mathrm{B}$ and $3.5 \mathrm{mg} / \mathrm{L} \mathrm{Li}$ solution, which has a lower $\mathrm{pH}_{25}$.

Nyquist plots for the 304L SS in two tested solutions are presented in Figure 5. In Figure 5, two somewhat unfinished capacitance arcs could be seen on the Nyquist diagram. The impedance is observed to be $\mathrm{pH}_{25}$ dependence, such that the imaginary component becomes suppressed, as the decrease of $\mathrm{pH}_{25}$. This form of impedance is consistent with the occurrence of a charge-transfer reaction in a porous film of finite thickness. ${ }^{14}$ The impedance spectra were analyzed using the equivalent electrical circuit shown in Figure 6, ${ }^{15-17}$ where $R_{\text {sol }}$ represents the electrolyte resistance, $R_{\mathrm{t}}$ represents the film resistance, $Q$ corresponds to the pseudo-capacitance of the film, expressed using the CPE. The use of a constant phase element (CPE) was necessary ${ }^{18,19}$ due to

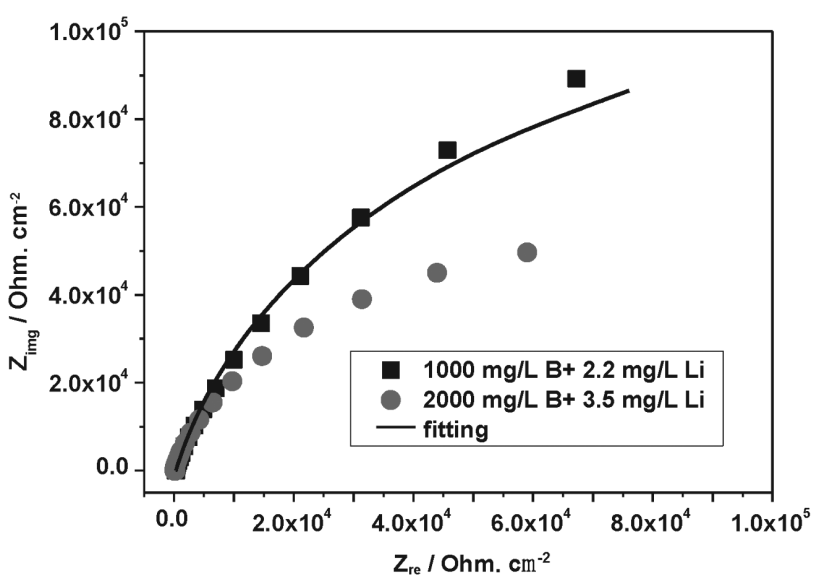

Figure 5: EIS of 304L in B-Li solution

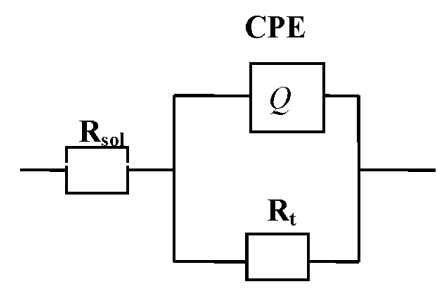

Figure 6: Equivalent circuits tested to model the experimental EIS data

the distribution of relaxation times resulting from heterogeneities at the electrode surface.

The impedance of the CPE is given by:

$$
Z_{\mathrm{Q}}=(j \omega)^{-n} / Y_{0}
$$

$Y_{0}$ corresponds to the pseudo-capacitance of the film, the factor $n$, defined as the CPE power, is an adjustable parameter that always lies between 0.5 and 1 . When $n=1$, the CPE describes an ideal capacitor. For $0.5<n$ $<1$, the CPE describes the distribution of dielectric relaxation times in the frequency space. The fitted parameters are listed in Table 2. It can be seen from Table 2 that $R_{t}$ in the $1000 \mathrm{mg} / \mathrm{L} \mathrm{B}$ and $2.2 \mathrm{mg} / \mathrm{L} \mathrm{Li}$ solution is larger than that in the $2000 \mathrm{mg} / \mathrm{L} \mathrm{B}$ and $3.5 \mathrm{mg} / \mathrm{L} \mathrm{Li}$ solution, indicating that the resistance of the charge transfer in the passive film is higher. The protective ability of the passive film formed in the former will be better than the latter. The $Y_{0}$ of the passive film formed in $1000 \mathrm{mg} / \mathrm{L} \mathrm{B}$ and $2.2 \mathrm{mg} / \mathrm{L} \mathrm{Li}$ solution is smaller than that of the $2000 \mathrm{mg} / \mathrm{L} \mathrm{B}$ and $3.5 \mathrm{mg} / \mathrm{L} \mathrm{Li}$ solution, indicating that the passive film formed on 304L SS in $1000 \mathrm{mg} / \mathrm{L} \mathrm{B}+2.2 \mathrm{mg} / \mathrm{L} \mathrm{Li}$ solution has a lower reactivity and a better corrosion resistance.

\section{CONCLUSIONS}

The oxide film of 304L SS immersed in two B/Li solutions is mainly composed of magnetite. The ratio of $\mathrm{B} / \mathrm{Li}$ in the tested solutions has no significant influence on the crystal structure of the oxide film, but the oxide film immersed in the $1000 \mathrm{mg} / \mathrm{L} \mathrm{B}$ and $2.2 \mathrm{mg} / \mathrm{L} \mathrm{Li} \mathrm{so-}$ lution is thicker than that in the $2000 \mathrm{mg} / \mathrm{L} \mathrm{B}$ and $3.5 \mathrm{mg} / \mathrm{Li}$ solution. The oxide film of 304L SS formed in the $1000 \mathrm{mg} / \mathrm{L} \mathrm{B}$ and $2.2 \mathrm{mg} / \mathrm{L} \mathrm{Li}$ solution is more stable than that in the $2000 \mathrm{mg} / \mathrm{L} \mathrm{B}$ and $3.5 \mathrm{mg} / \mathrm{L} \mathrm{Li}$ solution because of the low solubility of the oxide film in the high $\mathrm{pH} \mathrm{B} / \mathrm{Li}$ solution. The electrochemical results show that the pitting potential and the charge-transfer resistance of the $304 \mathrm{~L} \mathrm{SS}$ in $2000 \mathrm{mg} / \mathrm{L} \mathrm{B}$ and $3.5 \mathrm{mg} / \mathrm{L} \mathrm{Li}$ solution was lower than in the $1000 \mathrm{mg} / \mathrm{L} \mathrm{B}$ and $2.2 \mathrm{mg} / \mathrm{L} \mathrm{Li}$

Table 2: Equivalent circuit parameters for 304L SS in two test solutions

\begin{tabular}{|c|c|c|c|c|}
\hline Solution & $R_{\text {sol }} /\left(\Omega^{-1} \cdot \mathrm{cm}^{-2}\right)$ & $Y_{\mathrm{O}} /\left(\Omega^{-1} \cdot \mathrm{cm}^{-2} \cdot \mathrm{S}^{\mathrm{n}}\right)$ & $n$ & $R_{t} /\left(\Omega^{-1} \cdot \mathrm{cm}^{-2}\right)$ \\
\hline $1000 \mathrm{mg} / \mathrm{L} \mathrm{B}+2.2 \mathrm{mg} / \mathrm{L} \mathrm{Li}$ & $2.99 \times 10^{2}$ & $7.12 \times 10^{-5}$ & 0.86 & $2.65 \times 10^{5}$ \\
\hline $2000 \mathrm{mg} / \mathrm{L} \mathrm{B}+3.5 \mathrm{mg} / \mathrm{L} \mathrm{Li}$ & $1.30 \times 10^{2}$ & $8.29 \times 10^{-5}$ & 0.90 & $10.02 \times 10^{4}$ \\
\hline
\end{tabular}


solution. So, the high $\mathrm{pH} \mathrm{B} / \mathrm{Li}$ solution is more beneficial to forming a stable oxide film for the 304LSS.

\section{REFERENCES}

${ }^{1}$ R. Nasir, S. M. Mirza, N. M. Mirza, Evaluation of corrosion product activity in a typical PWR with extended cycles and flow rate perturbations, World J. Nucl. Sci. Technol., 7 (2017), 24-34, doi:creativecommons.org/licenses/by/4.0/

${ }^{2}$ K. Garbett, Corrosion products behavior during hot functional tests and normal operation in cycle at Sizewell B., Water Chemistry of Nuclear reactor System 7, Bournemouth 1996, 443-450

${ }^{3} \mathrm{~K}$. Garbett, Corrosion product behavior in the Sizewell B PWR,Proc. of the JAIF International Conference on Water Chemistry in Nuclear Power Plant, 1998, 65-72

${ }^{4}$ W. J. Kuang, X. Q. Wu, E. H. Han, The oxidation behaviour of 304 stainless steel in oxygenated high temperature water, Corros. Sci., 52 (2010), 4081-4087, doi:10.1016/j.corsci.2010.09.001

${ }^{5}$ W. J. Kuang, X. Q. Wu, E. H. Han, L. Q. Ruan, Effect of nickel ion from autoclave material on oxidation behaviour of 304 stainless steel in oxygenated high temperature water, Corros. Sci., 53 (2011), 1107-1114, doi:10.1016/j.corsci.2010.12.008

${ }^{6}$ T. Yamamoto, K. Fushimi, M. Seo, S. Tsuri, T. Adachi, H. Habazaki, Depassivation-repassivation behavior of type-312L stainless steel in $\mathrm{NaCl}$ solution investigated by the micro-indentation, Corros. Sci., 51 (2009), 1545-1553, dio:10.1016/j.corsci.2008.11.020

${ }^{7}$ V. Vignal, H. Zhang, O. Delrue, O. Heintz, I. Popa, J. Peultier, Influence of long-term ageing in solution containing chloride ions on the passivity and the corrosion resistance of duplex stainless steels, Corros. Sci., 53 (2011), 894-903, doi:10.1016/j.corsci.2010.11.011

${ }^{8}$ H. Sun, X. Wu, E. H. Han, Y. Wei, Effects of $\mathrm{pH}$ and dissolved oxygen on electrochemical behavior and oxide films of 304SS in borated and lithiated high temperature water, Corros. Sci., 59 (2012), 334-342, doi:10.1016/j.corsci.2012.03.022

${ }^{9}$ W. J. Kuang, X. Q. Wu, E. H. Han, Influence of dissolved oxygen concentration on the oxide film formed on 304 stainless steel in high temperature water, Corros. Sci., 63 (2012), 25-266, doi:10.1016/ j.corsci.2012.06.007

${ }^{10}$ H. Shi , Z. G. Gao, Z. B. Fan, Y. Y. Ding, Y. X. Qiao, Z. Y. Zhu, Corrosion behavior of alloy C-276 in supercritical water, Adv. Mater. Sci. Eng., 1027640 (2018), 1-6, doi:10.1155/2018/1027640

${ }^{11}$ S. E. Ziemniak, M. Hanson, Corrosion behavior of 304 stainless steel in high temperature, hydrogenated water, Corros. Sci., 44 (2002), 2209-2230, doi:10.1016/S0010-938X(02)00004-5

${ }^{12}$ W. J. Kuang, X. Wu, E. H. Han, J. Rao, Effect of alternately changing the dissolved $\mathrm{Ni}$ ion concentration on the oxidation of 304 stainless steel in oxygenated high temperature water, Corros. Sci., 53 (2011), 2582-2591, doi:10.1016/j.corsci.2011.04.016

${ }^{13}$ D. Perkins, EPRI ChemWorks Tools Software User's Manual, Version 4.2, Electric Power Research Institute, Palo Alto, CA: 3002004917

${ }^{14}$ Y. X. Qiao, Y. G. Zheng, W. Ke, P. C. Okafor, Electrochemical behavior of high nitrogen stainless steel in acidic solutions, Corros. Sci., 51 (2009), 979-986, doi:10.1016/j.corsci.2009.02.026

${ }^{15}$ C. M. Abreu, M. J. Cristóbal, R. Losada, X. R. Nóvoa, G. Pena, M. C. Pérez, Comparative study of passive films of different stainless steels developed on alkaline medium, Electrochimi. Acta, 49 (2004), 3049-3056, doi:10.1016/j.electacta.2004.01.064

${ }^{16}$ S. S. El-egamy, W. A. Badaway, Passivity and passivity breakdown of 304 stainless steel in alkaline sodium sulphate solutions, J. Appl. Electrochem., 34 (2004), 1153-1158, doi:0.1007/s10800-004-1709-x

${ }^{17}$ A. V. Alves, C. M. A. Brett, Characterization of passive films formed on mild steels in bicarbonate solution by EIS, Electrochimi. Acta, 47 (2002), 2081-2091, doi:0.1016/S0013-4686(02)00077-4

${ }^{18}$ A. Carnot, I. Frateur, S. Zanna, B. Tribollet, I. Dubois-Brugger, P. Marcus, Corrosion mechanisms of steel concrete moulds in contact with a demoulding agent studied by EIS and XPS, Corros. Sci., 45 (2003), 2513-2524, doi:10.1016/S0010-938X(03)00076-3

${ }^{19}$ C. Hitz, A. Lasia, Experimental study and modeling of impedance of the HER on porous Ni electrodes, J. Electroanal. Chem., 500 (2001), 213-222, doi:0.1016/S0022-0728(00)00317-X 